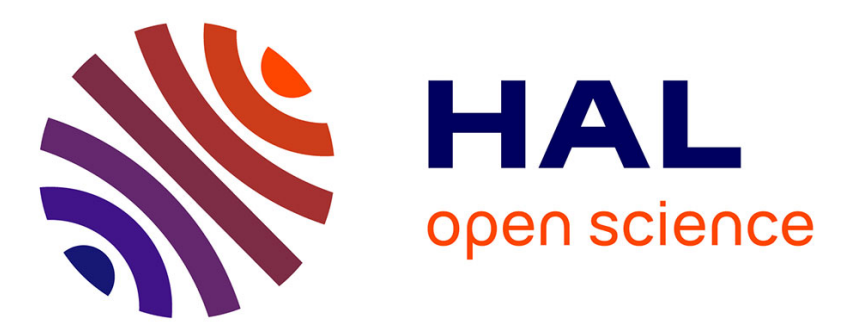

\title{
A molecular assay for the proactive detection of target site-based resistance to herbicides inhibiting acetolactate synthase in Alopecurus myosuroides.
}

Christophe C. Delye, Karelle Boucansaud

\section{- To cite this version:}

Christophe C. Delye, Karelle Boucansaud. A molecular assay for the proactive detection of target site-based resistance to herbicides inhibiting acetolactate synthase in Alopecurus myosuroides.. Weed Research, 2008, 48 (2), pp.97-101. 10.1111/j.1365-3180.2007.00615.x . hal-02660912

\section{HAL Id: hal-02660912 \\ https://hal.inrae.fr/hal-02660912}

Submitted on 30 May 2020

HAL is a multi-disciplinary open access archive for the deposit and dissemination of scientific research documents, whether they are published or not. The documents may come from teaching and research institutions in France or abroad, or from public or private research centers.
L'archive ouverte pluridisciplinaire HAL, est destinée au dépôt et à la diffusion de documents scientifiques de niveau recherche, publiés ou non, émanant des établissements d'enseignement et de recherche français ou étrangers, des laboratoires publics ou privés. 


\title{
INSIGHTS
}

\section{A molecular assay for the proactive detection of target site-based resistance to herbicides inhibiting acetolactate synthase in Alopecurus myosuroides}

\author{
C DÉLYE \& K BOUCANSAUD \\ INRA, UMR1210 Biologie et Gestion des Adventices, Dijon, France
}

Received 26 July 2007

Revised version accepted 13 November 2007

\section{Summary}

Acetolactate synthase (ALS) inhibitors are the most resistance-prone herbicide group. Rapid resistance diagnosis is thus of importance for their optimal use. We formulate rules to use the derived cleaved amplified polymorphic sequence method to develop molecular tools detecting a change at a given codon, the nature of which is unknown. We applied them to Alopecurus myosuroides (black grass) to develop assays targeting ALS codons A122, P197, A205, W574 and S653 that are
\end{abstract}

crucial for herbicide sensitivity. These assays detected W574L or P197T, or both substitutions, in most plants analysed from a field where ALS inhibitors failed after 3 years of use. Similar assays can easily be set up for any species. Given the rapidity of selection for resistance to ALS inhibitors, these assays should be very useful in proactive herbicide resistance diagnosis.

Keywords: acetolactate synthase, ALS, AHAS, dCAPS, herbicide, PCR, proactive diagnosis, mutation, resistance, sulfonylurea, grass weed.

Délye C \& Boucansaud K (2008). A molecular assay for the proactive detection of target site-based resistance to herbicides inhibiting acetolactate synthase in Alopecurus myosuroides. Weed Research 48, 97-101.

\section{Introduction}

Herbicides targeting acetolactate synthase (ALS, EC 2.2.1.6) are among the most used herbicides worldwide (Tranel \& Wright, 2002; Corbett \& Tardif, 2006). They are also the most resistance-prone herbicide group to date, with resistant plants reported in at least 95 weed species (Heap, 2007). Resistance diagnosis is thus of importance for the optimal use of ALS inhibitors. ALS-based resistance is considered to play the major role in resistance to ALS inhibitors (Corbett \& Tardif, 2006). Using Arabidopsis thaliana (L.) Heynh. ALS sequence as a reference for amino acid numbering (Tranel \& Wright, 2002), most ALS-based resistance cases reported to date are due to substitutions at codons A122, P197, A205, W574 or S653 (Tranel et al., 2007). Resistant ALS allele detection proved the quickest and most accurate way of diagnosing resistance to ALS inhibitors (Corbett \& Tardif, 2006). Molecular, DNA-based assays most often based upon the loss/gain of a restriction enzyme recognition site [polymerase chain reaction (PCR)-restriction fragmentlength polymorphism (RFLP)], or upon direct specific amplification of the mutant allele (allele-specific PCR), have consequently been developed to detect resistant ALS alleles in various weed species where resistance arose (Corbett \& Tardif, 2006). However, different possible substitutions have been reported at a given amino acid position, e.g. nine substitutions are known at codon 197 (Tranel et al., 2007). The molecular tools hitherto developed were therefore set up on the basis of ALS sequences from resistant plants, after herbicide resistance confirmation (Corbett \& Tardif, 2006). This takes time and is to be performed each time a new 
mutation arises, which is not compatible with proactive resistance management.

Herein, we considered ALS-based resistance in Alopecurus myosuroides Huds. (black grass), a noxious, widespread grass weed of winter crops in Europe. In France, ALS inhibitors have been heavily used against A. myosuroides since 2003. As a consequence, herbicide application failures are starting to be reported. To promptly confirm ALS-based resistance, we developed five molecular assays, each detecting any mutation causing an amino acid substitution at one of the positions 122, 197, 205, 574 or 673 in A. myosuroides ALS. All assays are based upon the derived cleaved polymorphic amplified sequence method (dCAPS; Neff et al., 1998), already successfully used to detect known mutations endowing herbicide resistance (Kaundun \& Windass, 2006).

\section{Designing dCAPS assays}

The dCAPS technique uses PCR to create a restriction enzyme recognition site in a sequence where none exists, detecting nucleotide polymorphisms on the basis of the gain (amplicon is digested) or loss (amplicon is not undigested) of this site. One of the PCR primers is located close to the variable nucleotide and contains mismatched nucleotide(s) so as to create a restriction enzyme recognition site encompassing the variable nucleotide (Neff et al., 1998). dCAPS primers were generated using the software DCAPS FINDER 2.0 (Neff et al., 2002). dCAPS assays specifically cutting amplicons containing wild-type codons in A. myosuroides ALS (EMBL/GenBank accession AJ437300) were subsequently designed following five rules: (1) dCAPS fragments 150-350 nucleotide long and (2) dCAPS

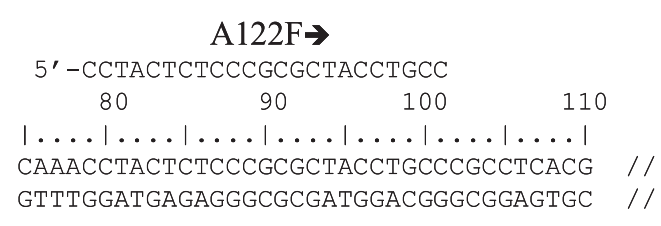

$\mathrm{A} 122 \mathrm{~F} \rightarrow$

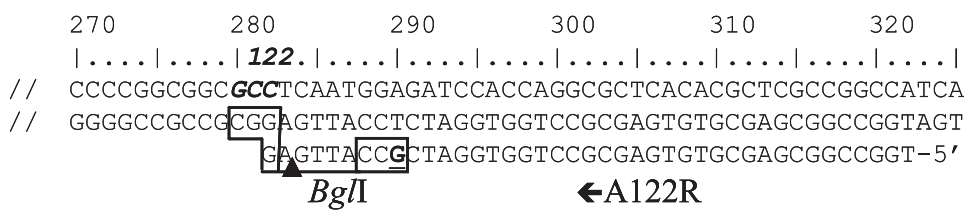
GAGTTACCGFTAGGTGGTCCGCGAGTGTGCGAGCGGCCGGT-5' $B g l \mathrm{I}$

$\leftarrow \mathrm{A} 122 \mathrm{R}$

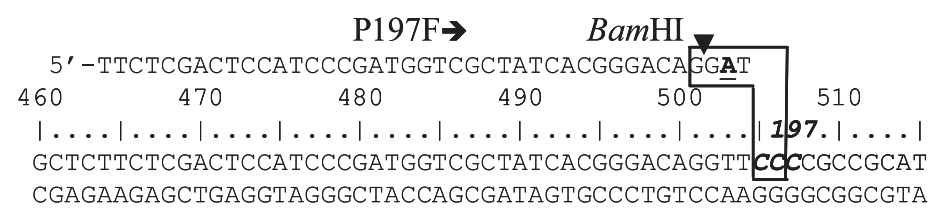

\section{$\mathrm{P} 197 \mathrm{~F} \rightarrow$}

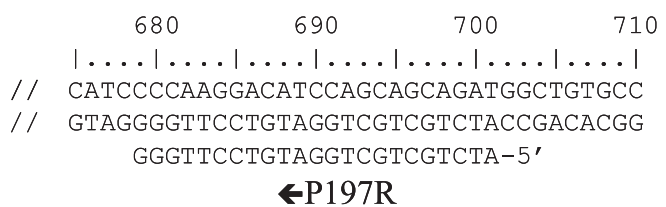

$\leftarrow$ P197R

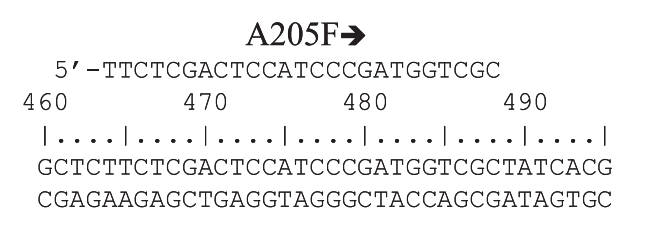

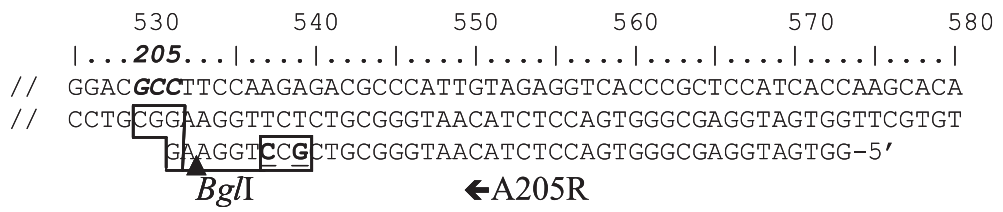

\section{$\mathrm{W} 574 \mathrm{~F} \rightarrow$}

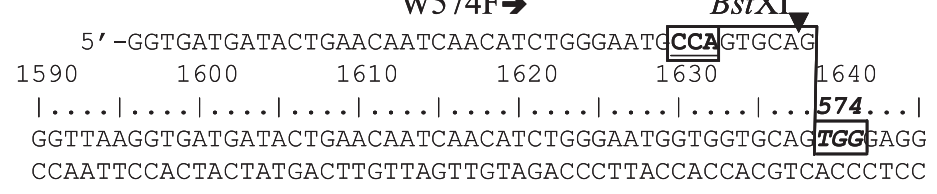

CCAATTCCACTACTATGACTTGTTAGTTGTAGACCCTTACCACCACGTCACCCTCC

\section{$\begin{array}{llll}1980 & 1990 & 2000 & 2010\end{array}$ $|\ldots| \ldots . \ldots|\ldots| \ldots|\ldots| \ldots|\ldots|$ // CAATGTGCCTGATCAGCATGATGCTGGTGTATGtTA // GTTACACGGACTAGTCGTACTACGACCACATACAAT GGACTAGTCGTACTACGACCACATA-5'}

$\leftarrow$ WSR

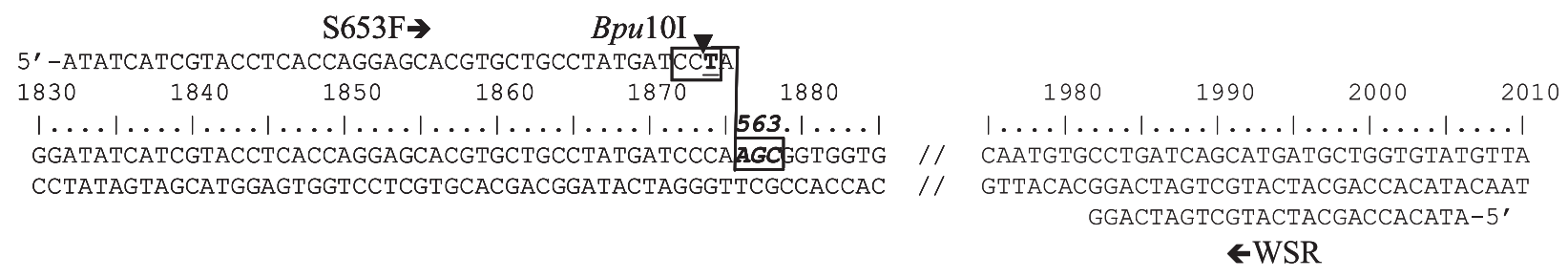

Fig. 1 Primer positions. Nucleotide positions in A. myosuroides ALS are above the sequence. Forward primers are above DNA plus strand, and reverse primers are below DNA minus strand. Targeted codons are indicated by bold italics. Mismatching nucleotides in dCAPS primers are in bold underlined. Restriction enzyme recognition sites are boxed, and cutting site positions are arrowed. 
primers about 40 nucleotide long to enable easy discrimination of undigested and digested (about $40 \mathrm{bp}$ removed, see Fig. 1) amplicons by standard agarose gel electrophoresis; (3) no mismatch at the last dCAPS primer 3' nucleotide; (4) all nucleotides in the restriction enzyme recognition site exclusively located in the primer sequence and in the part of the targeted codon where any variation would cause amino-acid substitution; and (5) no other restriction enzyme recognition site in the amplicon. When several restriction enzymes fulfilled rules (4) and (5), the cheapest one was selected. Primers and restriction enzymes are given in Table 1. Positions of primers and restriction enzyme recognition sites in A. myosuroides ALS sequence are shown on Fig. 1.

Rule (4) was set up for two reasons. First, if nucleotides in the restriction enzyme recognition site were located elsewhere, silent changes or variation at positions not involved in herbicide resistance would lead to false detection of resistant ALS alleles. Second, the genetic code is degenerated. Thus, not all nucleotide substitutions cause amino acid variation. In A. myosuroides, $\mathrm{P} 197$ is encoded by CCC, and A122 and A205 are both encoded by GCC. A proline residue is encoded by $\mathrm{CCN}$, an alanine by GCN (N is any nucleotide). Only changes at the two first nucleotides cause amino acid substitution at these codons. Recognition sites of the selected enzymes (BamHI for P197, Bg/I for A122 and A205) thus encompass four nucleotides in dCAPS primers and the two first nucleotides in each targeted codon (Table 1, Fig. 1). Only codon TGG encodes a tryptophane residue. Any change at this codon causes amino acid substitution. BstXI was selected, the recog- nition site of which encompasses three nucleotides in primer W574F and the three nucleotides in codon 574 (Table 1, Fig. 1). In A. myosuroides, S653 is encoded by AGC. A serine residue is encoded by TCN or AGY. AGC-to-AGG and AGC-to-AGA changes cause an S-to- $\mathrm{R}$ substitution, while AGC-to-AGT is silent. Any other change at codon 653 causes amino acid substitution. Bpu10I was selected, the recognition site of which encompasses three nucleotides in dCAPS primer $\mathrm{S} 653 \mathrm{~F}$ and three in codon 653 (Table 1, Fig. 1). We deemed the possible false-positive diagnosis of the occurrence of mutant ALS caused by a silent AGC-to-AGT change to be a lesser flaw than not detecting the two other changes causing an S-to-R substitution.

DNA extraction and PCR mixes were as described (Délye et al., 2002). Primers targeting A122 and W574 were used at $0.2 \mu \mathrm{m}$ each. Primers targeting other codons were used at $0.4 \mu \mathrm{m}$ each. Cycling programs consisted of $95^{\circ} \mathrm{C}$ for $5 \mathrm{~min}$ followed by 37 cycles at $95^{\circ} \mathrm{C}$ for $5 \mathrm{~s}$, Tm (annealing temperature of the primer pair) (Table 1) for $10 \mathrm{~s}$ and $72^{\circ} \mathrm{C}$ for $30 \mathrm{~s}$. Digestions were performed at $37^{\circ} \mathrm{C}$ for $3 \mathrm{~h}$ in PCR mixes added with $5 \mathrm{U}$ enzyme (Fermentas, Vilnius, Lithuania), $0.7 \mu \mathrm{L}$ of $10 \mathrm{x}$ enzyme buffer and $5 \mu \mathrm{L}$ of water. dCAPS patterns were visualised by electrophoresis on $3 \%$ $(\mathrm{wt} / V$ ) agarose gels run in $0.5 \mathrm{x}$ TBE buffer, except for A205 (3.5\% wt/ $V$ agarose).

\section{Testing and validating dCAPS}

All assays were set up using 15 plants from an A. myosuroides accession never sprayed with ALS inhibitors. Digested and undigested amplicons were

Table 1 dCAPS primers and restriction enzymes

\begin{tabular}{|c|c|c|c|c|c|c|}
\hline $\begin{array}{l}\text { Target } \\
\text { codons }\end{array}$ & Primers* & Sequence $\left(5^{\prime}-3^{\prime}\right) \dagger$ & $\begin{array}{l}\mathrm{Tm} \\
\text { (PCR) }\end{array}$ & $\begin{array}{l}\text { Restriction } \\
\text { enzyme, } \\
\text { recognition } \\
\text { site }\end{array}$ & $\begin{array}{l}\text { Expected } \\
\text { patterns } \\
\text { (fragment } \\
\text { in bp) } \\
\text { WTt }\end{array}$ & $\begin{array}{l}\text { dCAPS } \\
\text { t sizes } \\
\text { Mutant }\end{array}$ \\
\hline A122 & $\begin{array}{l}\text { A122F } \\
\text { A122R } \S\end{array}$ & $\begin{array}{l}\text { CCTACTCTCCCGCGCTACCTGCC } \\
\text { TGGCCGGCGAGCGTGTGAGCGCCTGGTGGATCGCCATTGAG }\end{array}$ & $70^{\circ} \mathrm{C}$ & $B g l l, \mathrm{GCCN}_{5} \mathrm{GGC}$ & 36,208 & 244 \\
\hline P197 & $\begin{array}{l}\text { P197F§ } \\
\text { P197R }\end{array}$ & 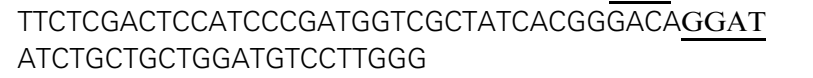 & $60^{\circ} \mathrm{C}$ & BamHI, GGATCC & 38,200 & 238 \\
\hline A205 & $\begin{array}{l}\text { A205F } \\
\text { A205R } \S\end{array}$ & $\begin{array}{l}\text { TTCTCGACTCCATCCCGATGGTCGC } \\
\text { GGTGATGGAGCGGGGACCTCTACAATGGGCGTCGCCTGGAAG }\end{array}$ & $55^{\circ} \mathrm{C}$ & $B g \|, \mathrm{GCCN}_{5} \mathrm{GGC}$ & 41,69 & 110 \\
\hline W574 & $\begin{array}{l}\text { W574F§ } \\
\text { WSR }\end{array}$ & 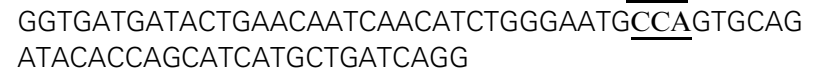 & $60^{\circ} \mathrm{C}$ & $B s t \mathrm{XI}, \mathrm{CCAN}_{6} \mathrm{TGG}$ & 39,372 & 411 \\
\hline S653 & $\begin{array}{l}\text { S653F§ } \\
\text { WSR }\end{array}$ & $\begin{array}{l}\text { ATCATCGTACCTCACCAGGAGCACGTGCTGCCTATGATCCTA } \\
\text { ATACACCAGCATCATGCTGATCAGG }\end{array}$ & $65^{\circ} \mathrm{C}$ & Bpu10I, CCTNAGC & 40,133 & 173 \\
\hline
\end{tabular}

* Primer name ending with $\mathrm{F}$, forward primer; primer name ending with $\mathrm{R}$, reverse primer.

$\dagger$ Nucleotide(s) in bold are modified from A. myosuroides ALS sequence in order to create a recognition site for the restriction enzyme used. Nucleotides belonging to the enzyme restriction site are underlined. 


\begin{tabular}{|c|c|c|c|}
\hline $\begin{array}{l}\text { Growing } \\
\text { season }\end{array}$ & Crop & Herbicide(s) applied & $\begin{array}{l}\% A . \\
\text { myosuroides } \\
\text { control }\end{array}$ \\
\hline \multirow[t]{3}{*}{ 2005-2006 } & \multirow[t]{3}{*}{ Wheat } & Mesosulfuron* + iodosulfuron* & 0 \\
\hline & & Imazamethabenz ${ }^{*}+$ isoproturon $\dagger$ & $30-40$ \\
\hline & & Mesosulfuron* + iodosulfuron* & 5060 \\
\hline 2004-2005 & Wheat & Mesosulfuron* + iodosulfuron* & 70 \\
\hline 2003-2004 & Wheat & Mesosulfuron* + iodosulfuron* & 100 \\
\hline $2002-2003$ & Wheat & Clodinafop $\ddagger$ & 100 \\
\hline 2001-2002 & Wheat & Clodinafop $\ddagger$ & $90-100$ \\
\hline 2000-2001 & Wheat & Clodinafopt & 90 \\
\hline
\end{tabular}

Table 2 Record of herbicide application on an A. myosuroides accession collected in 2006 in Sommepy (NE France)
*Herbicide inhibiting ALS (HRAC group B).

$\dagger$ Herbicide inhibiting photosystem II (HRAC group C).

\$Herbicide inhibiting acetyl-CoA carboxylase (HRAC group A). electrophoresed side by side. After enzyme digestion, all plants yielded the expected wild-type patterns that were readily discriminated from undigested amplicons on agarose gels (not shown).

We then investigated a field where ALS-inhibiting herbicides gave very poor $A$. myosuroides control after only 3 years of use, with three applications during the last growing season (Table 2). Seeds were randomly sampled from about 150 surviving plants, allowed to germinate and 100 seedlings were analysed using the five dCAPS assays. No seedling contained mutations at codons A122, A205 and S653 (not shown). Six plants also did not contain mutations at codons P197 and W574. Ten plants were homozygous mutants at codon 197 and 77 plants at codon 574. The remaining seven plants were heterozygous mutants for both codons. dCAPS patterns obtained for codons 197 and 574 are illustrated in Fig. 2. dCAPS results were confirmed by

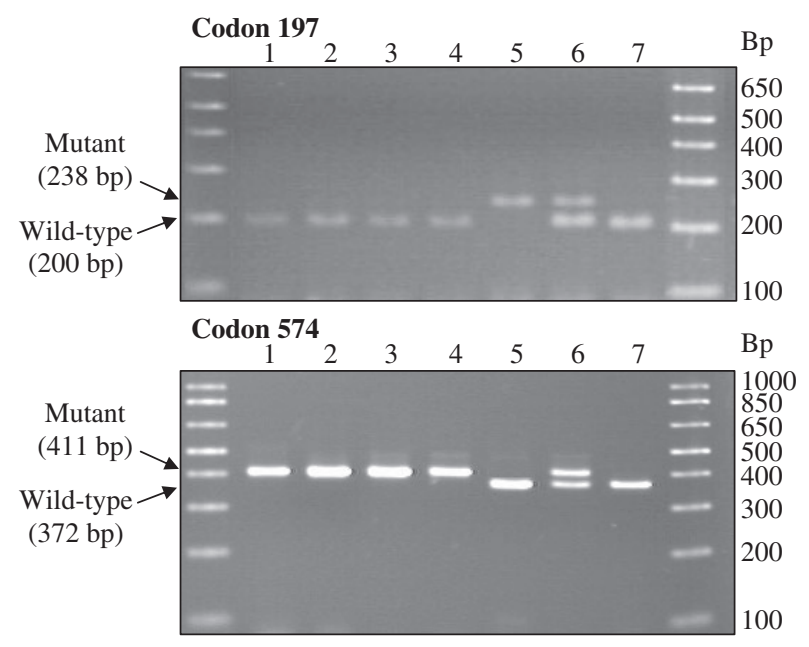

Fig. 2 dCAPS patterns of seven $A$. myosuroides seedlings analysed with dCAPS assays targeting codons 197 (top) and 574 (bottom). Lanes 1-4, homozygous mutants at codon 574; lane 5, homozygous mutant at codon 197; lane 6, double heterozygous mutant; lane 7, wild-type. sequencing six seedlings in each of the four categories identified. No change at any of the five codons was observed in seedlings where no mutation was detected using dCAPS. Seedlings where a mutation at codon 574 was detected all contained a TGG-to-TTG change causing a W-to-L substitution, as described in 14 other species (Tranel et al., 2007). Seedlings where a mutation at codon 197 was detected all contained a CCC-to-ACC change, causing a P-to-T substitution also described in five other species (Tranel et al., 2007). Double-heterozygous mutant seedlings all contained both changes. In other species, W574L and P197T substitutions were both reported to confer resistance to sulfonylureas (like mesosulfuron and iodosulfuron), while only W574L conferred resistance to imidazolinones (like imazamethabenz) (Tranel et al., 2007). Imazamethabenz use (Table 2) might be why L574 plants were predominant in the investigated field.

\section{Conclusions}

Similar to PCR-RFLP and allele-specific PCR, dCAPS enabled the discrimination of homozygous and heterozygous mutant plants. Allele-specific PCR requires known wild-type and mutant sequences to be developed. PCR-RFLP cannot be used for proactive resistance detection. First, a suitable restriction site including nucleotide position involved in resistance rarely exists in wild-type sequences. Second, restriction enzyme recognition sites contain at least four (most frequently six) nucleotides. There is therefore a significant risk for false detection of resistant alleles using PCR-RFLP, because of substitutions occurring outside nucleotide positions involved in resistance (see explanation to rule 4). dCAPS is therefore the only method so far detecting mutations of unknown nature at given codons. The assays described herein proved reliable for detecting mutations in A. myosuroides ALS. Following the five rules we set up, similar assays can easily be developed for any 
other species. Given the surprisingly fast selection for resistance observed in the A. myosuroides accession investigated, dCAPS assays targeting ALS should prove immensely useful for quick and proactive diagnosis of ALS-based resistance.

\section{Acknowledgements}

We are grateful to B. Couloume (Bayer CropScience France) for financial support and for providing A. myosuroides seeds.

\section{References}

Corbett C-AL \& TARdiF FJ (2006) Detection of resistance to acetolactate synthase inhibitors in weeds with emphasis on DNA-based techniques: a review. Pest Management Science 62, 584-597.

Délye C, MatéJicek A \& Gasquez J (2002) PCR-based detection of resistance to acetyl- CoA carboxylase-inhibiting herbicides in black-grass (Alopecurus myosuroides Huds) and ryegrass (Lolium rigidum Gaud). Pest Management Science 58, 474-478.

HEAP I (2007) International Survey of Herbicide-resistant Weeds (available at http://www.weedscience.org; last accessed 11 June 2007).

KAUNDUN SS \& WINDASS JD (2006) Derived cleaved amplified polymorphic sequence, a simple method to detect a key point mutation conferring acetyl CoA carboxylase inhibitor herbicide resistance in grass weeds. Weed Research 46, 34-39.

Neff MM, NefF JD, Chory J \& Pepper AE (1998) dCAPS, a simple technique for the genetic analysis of single nucleotide polymorphisms: experimental applications in Arabidopsis thaliana genetics. The Plant Journal 14, 387-392.

NefF MM, Turk E \& Kalishman M (2002) Web-based primer design for single nucleotide polymorphism analysis. Trends in Genetics 18, 613-615.

Tranel PJ \& Wright TR (2002) Resistance of weeds to ALSinhibiting herbicides: what have we learned? Weed Science 50, 700-712.

Tranel PJ, Wright TR \& Heap IN (2007) ALS Mutations from Resistant Weeds (available at http://www.weedscience.org; last accessed 24th July 2007). 